\title{
Construction of Electronic Examination and Education Platform for Financial Management
}

\author{
http://dx.doi.org/10.3991/ijet.v11i09.6117 \\ Ying $\mathrm{Yu}$ \\ Changsha Environmental Protection College, Changsha, China
}

\begin{abstract}
For existing shortcomings in the application of traditional and paperless examination systems in teaching financial management, this study proposed a scheme to construct electronic examination and education platform for the said course. Electronic examination system, which meets the needs of students, teachers, and administrators, has been achieved by analyzing the demand for electronic examination of financial management. This study introduced the design of the electronic examination system and the implementation method of main function modules thoroughly; analyzed the difficulties in module development process; and finally proposed the thought of further expansion and improvement. This research indicates that electronic examination system can objectively and fairly reflect the real level of students, improve examination efficiency, and promote finance teaching efficiency and effect well.
\end{abstract}

Index Terms-Financial Management, examination system, electronic

\section{INTRODUCTION}

With rapid development of economy and extensive application of information technology, creating new teaching mode of financial management under information environment has been an imperative [1]. Examination is the most important testing link in financial management teaching process and the entire teaching system [2]. Electronic examination is a revolution in the examination development history [3]. Since its emergence in 1990s, electronic examination has gradually become mature and started to be applied in all kinds of examination practice with the rapid development of computer science and technology, and continuous progress of testing theory. The innovation of ideas and practices in financial management teaching is due to its combination with electronic examination, which is significant for improving finance teaching efficiency and effect [4].

At present, most large-scale examinations (nationwide admission test and computer rank and civil servant examinations) utilizes test papers and standard answer sheets, where the answer sheets adopt the mode of electronic paper inspection [5]. Since the examination process has some loopholes, monitoring cheating. Thus, industry that offers various cheating and anti-cheating methods, such as peeping, taking an exam on behalf of others, and transferring answers, form in China. Existing examination modes and prevention means cannot effectively cope with the cheating methods mentioned previously [6, 7]. Moreover, survey result shows that although the ring prompts the end of examinations, monitoring teachers might distribute or collect the papers before or after the specified time in actual operation. This may result in $3 \mathrm{~min}$ to $5 \mathrm{~min}$ time error, which affects examination fairness. On this basis, electronic examination and education platform is a teaching examination mode that deserves more consideration.

Many studies have been done on electronic examination system. Bandele et al. [8] suggested that colleges should accept electronic examinations; expand programs for quality examinations and valid examination results; offer sufficient human and material resources to operate electronic examinations effectively; and make undergraduates able to obtain proficiency in computer and operation of electronic examinations for desirable success of the system. Osang [9] applied electronic examination system in college teaching in Nigeria, and results show that $81.9 \%$ of lecturers are proficient in computer, while the remaining $28.4 \%$ is being accustomed to the use of basic computer skills. This means that most academic lecturers in National Open University of Nigeria are proficient in computer. Thus, electronic examination system should be appreciated. The $63 \%$ of lecturers considered maple ta (the software) quite difficult, while $47.3 \%$ found it considerably easy after the training. This implies that electronic examination platform is significantly helpful to the lecturers. Relevant domestic research focuses on introduction to teachers' electronic paper inspection and students' identity recognition [10] Defects in the existing technology are as follows. First, electronic examination is generally applied in computer examination, and it has a few reports on the course of financial management. Second, for most electronic examination systems, monitoring teachers cannot synchronously control the equipment. Meanwhile, other relevant reports on electronic examination system under non-network environment fail to mention cheating control in examination and handling methods, because synchronous control of examination process and examination input mode control cannot be achieved.

Innovation of this study is reflected in the following aspects: Firstly, the study specially set up the function of examination paper management, such as automatic update of questions in examination papers and encryption of these papers; secondly, the function of supplying questions and corresponding answers in different orders is quite impressive. Consequently, the order and content of examination questions for each candidate are not the same, effectively preventing a variety of cheating commonly seen in examinations; finally, the system is featured by the access to continued examination if the power fails. In other words, in case of sudden power outage or computer failure in the process of taking an examination, candidates can continue the examination after the system is repaired. As a result, the entire examination process is not affected. 


\section{DESIGN AND IMPLEMENTATION OF ELECTRONIC EXAMINATION SYSTEM FOR FINANCIAL MANAGEMENT}

\section{A. Demand Analysis of electronic examination system for Financial Management}

The overall demand of electronic examination system for financial management specialty is to achieve paperless electronic examination. The customers of the electronic examination system are the students and teachers. Electronic examination system aims to achieve examination arrangement, question library management, intelligent test paper composition, online examination, automatic grading, score statistics, and analysis through the computers in campus network environment. System participants include examination affair administrator, teachers, and students. The function definition of all kinds of participants is shown in figure 1.

\section{B. System architecture}

The architecture of electronic examination system of financial management specialty is shown in figure 2 . Figure 2 shows that from user perspective, electronic examination system includes two types of services: 1) examination service on student computer; and 2) backstage application managed by teachers and teaching affairs office. In other words, the system has two entries. System architecture is shown in figure 2.

First, examinees authenticate their identity authentication. After they pass identity authentication, they will enter examination state and perform examination procedure. When the test ends, examinees answer the questions according to instructions. After submission, examinees cannot return to answering the questions again.

Examination affair administrators and teachers enter backstage interface to implement the following operations: examination paper generation, test question library management, and score statistics.

\section{Design of main system functions}

\section{1) Online examination management}

The examination mainly aims at financial management specialty. Before entering the examination interface, examinees will first browse the matters needing attention and the examination information. After the information is confirmed, they will enter the formal examination interface. In the examination process, the system will automatically save the answers to the server side. The structure of examination management function is shown in figure 3.

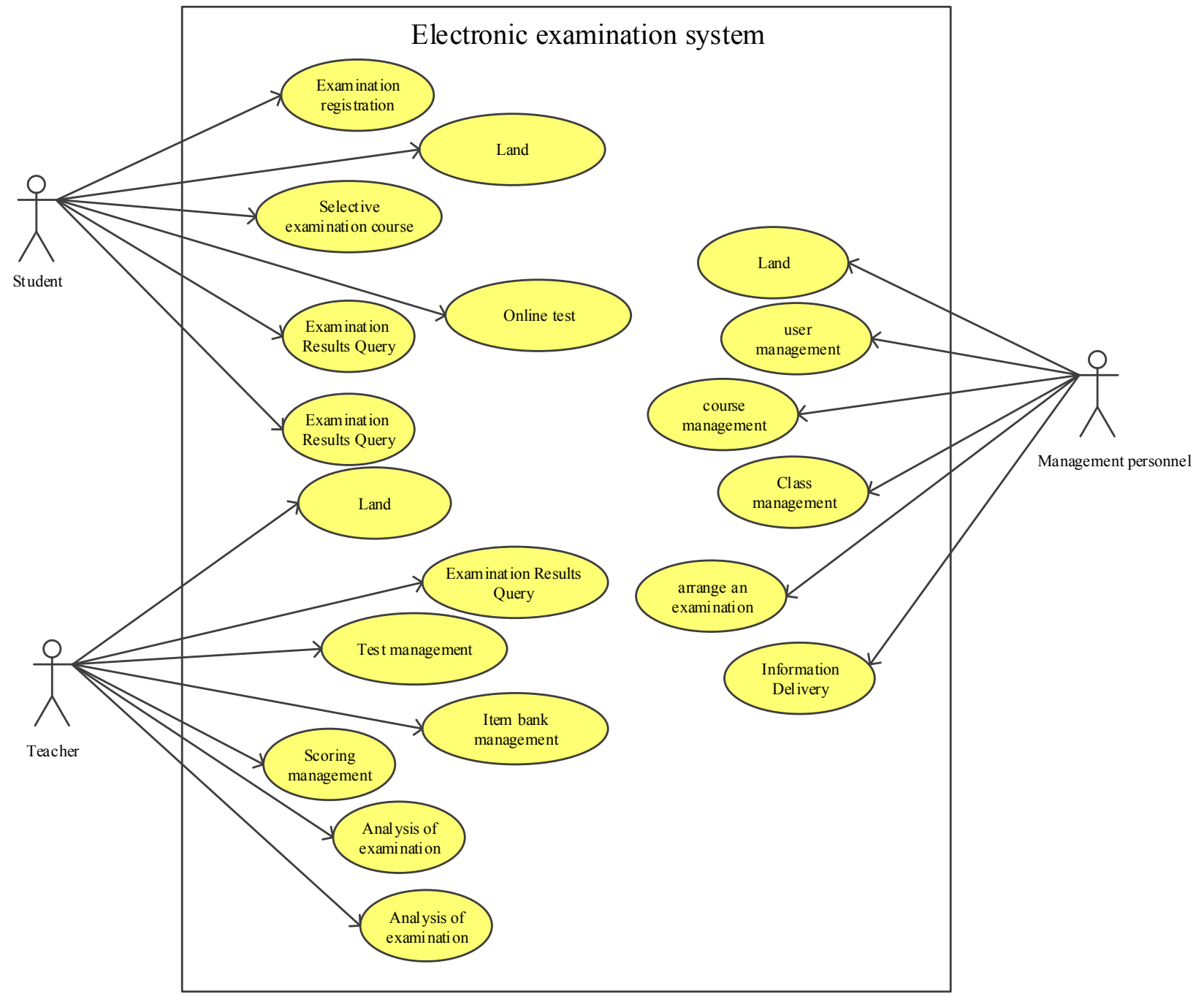

Figure 1. Diagram of electronic examination system 
PAPER

CONSTRUCTION OF ELECTRONIC EXAMINATION AND EDUCATION PLATFORM FOR FINANCIAL MANAGEMENT

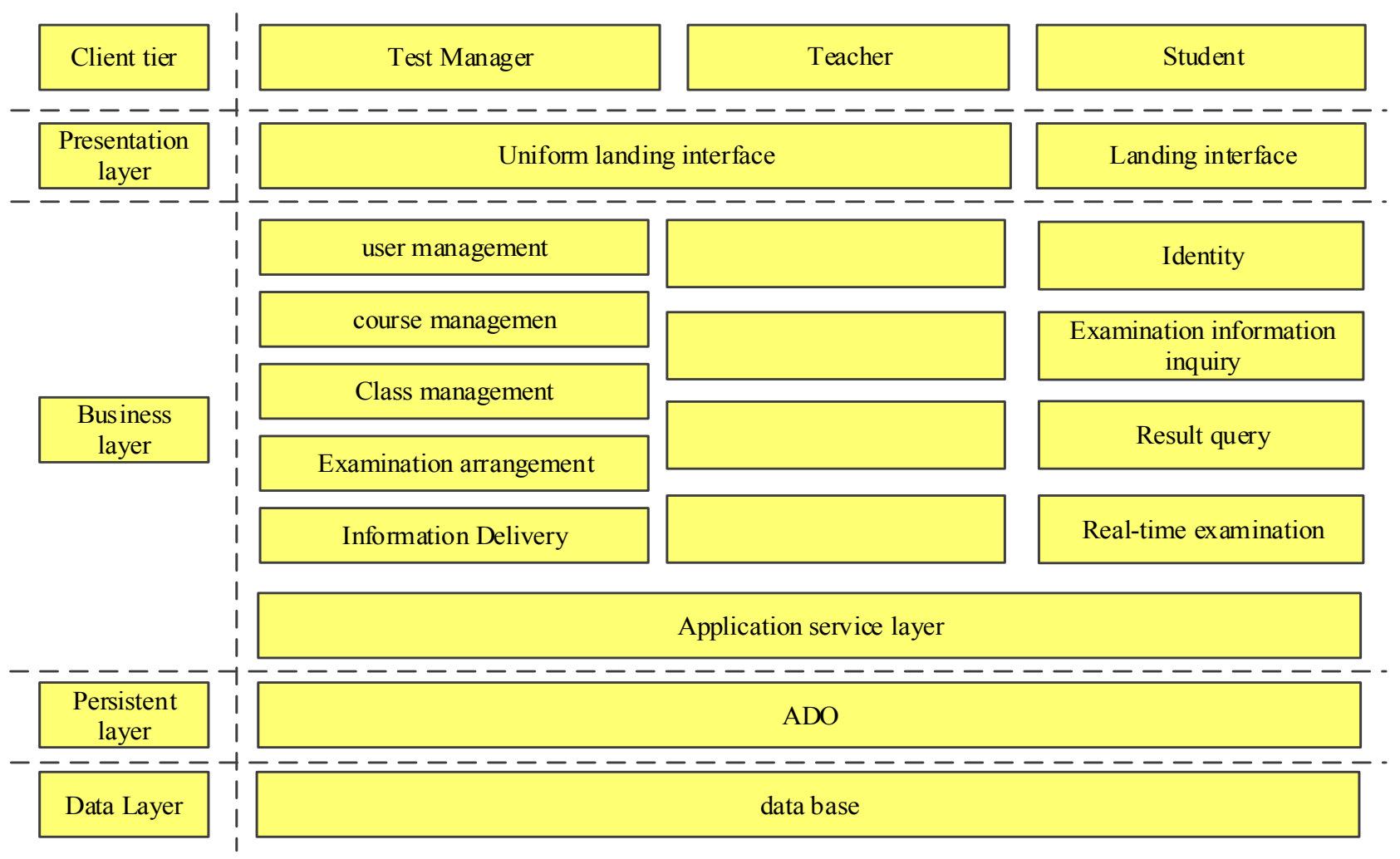

Figure 2. System architecture of electronic examination system

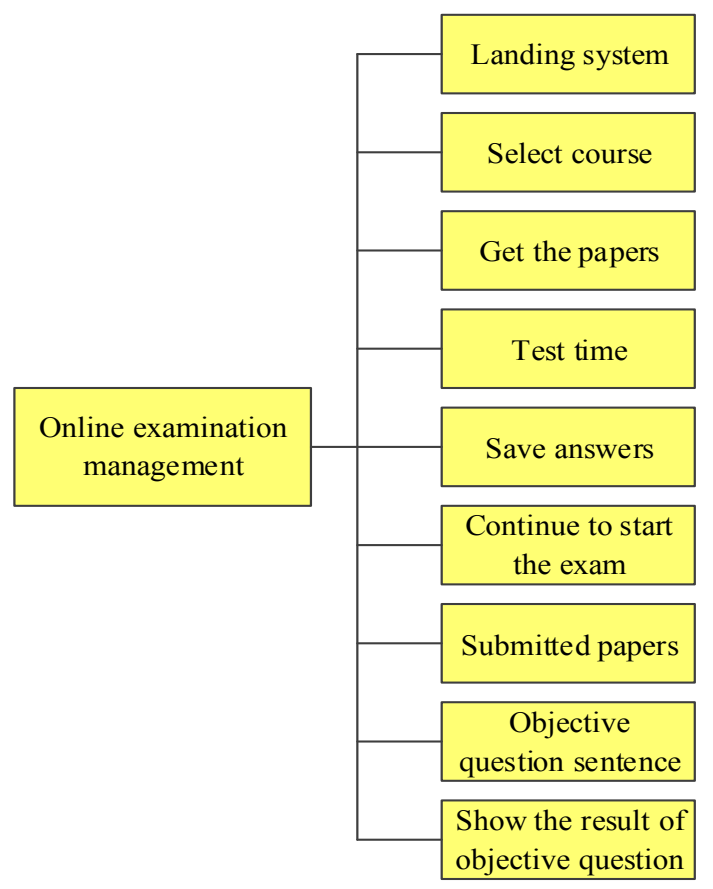

Figure 3. Structure diagram of online examination management

\section{2) Backstage management}

Backstage management is used by teaching affair administrators and teachers. Input of verification information for login, including account number and password, and the corresponding role (administrator or teacher), is necessary. The major functions are as follows:

1) Test question management. Test question management mainly involves question library establishment, maintenance, and update, as well as output of question library information as examination basis.

2) Examination paper management. Examination paper management mainly involves automatic generation and manual production of examination paper, and examination paper inquiry, appraisal, and examination paper output.

3) Score management. The functions contain examination paper inspection, score validation, score information management and maintenance, statistical analysis of score information, and score information output.

4) Security management. Security management achieves such functions as user function authorization and role authorization in the electronic examination system, as well as system locking. When the system is not used for the time being, most operation functions of the software can be locked through system locking function. Meanwhile, important data encryption and decryption functions can be achieved.

\section{System Implementation}

\section{1) Examinee information management}

Examinee information management includes the examinees' information input and maintenance, login interface design, and identity authentication. Examinee identity authentication is implemented through two aspects: student card and ID card number. Examinees need to input their authentication information for identity recognition.

\section{2) Real-time examination management}

Real-time examination includes examination client program, i.e., server program. Client functions include examinee information collection, random question extraction, examination, and examination data uploading. The interface is shown in figure 4 and 5. 


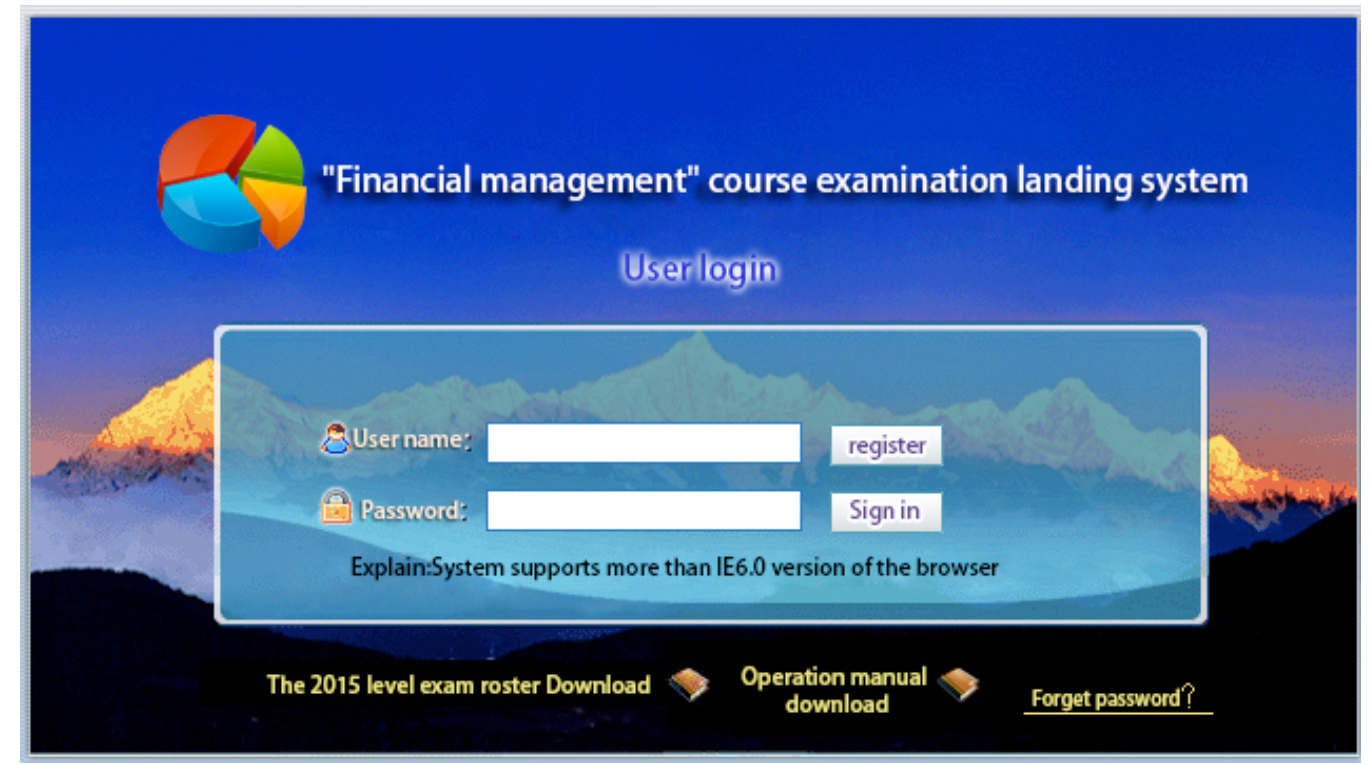

Figure 4. Examination interface

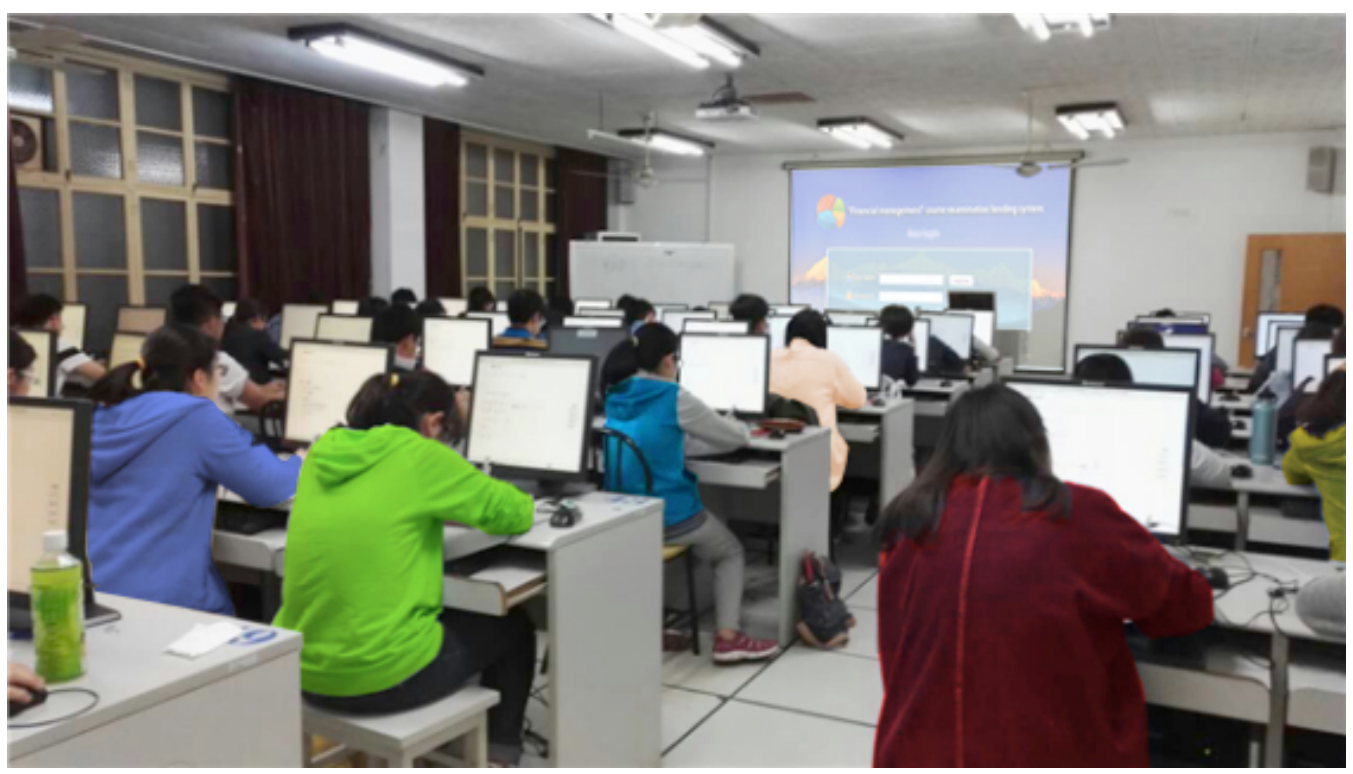

Figure 5. The display of Platform

\section{3) Score management}

Score management includes examination paper inspection, score encryption, and collection program. For objective questions, examinees' answers match with the correct results through the offset concept. The concept of set inclusion is applied to judge whether answers selected by users match with standard answers. Score data are encrypted dynamically, saved in file form, and then transmitted to the server to guarantee score security. Score collection is achieved through the server. After examinees complete the paper, a score reminder pops out automatically.

\section{4) Backstage management}

The teaching affair administrator logs in backstage examination system to set examination environment, room, plan management, and information management, and to inquire system records in real time. Examinee information management includes examination information collection, proofreading, and investigation. Functions of examination room management include arranging examination rooms, completing statistical inquiry of examination room information, and exporting that information.

\section{APPLICATION EFFECT OF ELECTRONIC} EXAMINATION AND EDUCATION PLATFORM IN FINANCIAL MANAGEMENT

Five hundred students were selected from 2015 financial management specialty in college as the experimental group, and they completed an electronic examination. Another 500 students were selected from 2014 financial management specialty as the control group, and they used the traditional examination method. The differences of both groups in faculty, and teaching content and conditions did not have any statistical significance. SPSS 18.0 software was used to analyze final examination scores of both groups. In addition, $t$ test was accomplished. $\mathrm{p} \leq 0.05$ means the difference has statistical significance. 


\section{A. Comparison of Examination Modes}

Test questions of the control group were revealed more easily than those of experimental group, and human interference factors were significant. Moreover, manual paper inspection might be easily influenced by subjective factors, which can cause unfairness in examination. Electronic examination achieved such functions as automatic combination of examination paper and automatic grading, saved much of manpower resource, effectively avoided erroneous judgment and human interference, and guaranteed examination fairness and openness. The examination system closely combined accountant occupational qualification and certified public accountant examination, such that students contacted occupational qualification examinations and other important examinations, which helped them improve their test-taking ability. The comparison of examination modes of students in both groups are shown in Table 1.

\section{B. Comparison of teachers' and students' satisfaction} for electronic examination

After the examination ended, 15 teachers and 300 students were selected from the experimental and control groups for satisfaction survey. Results show that students' and teachers' satisfaction for electronic examination mode is higher than that for traditional examination mode. $\mathrm{p}<$ 0.05 means the difference has statistical significance. Electronic examination did not only improve teachers' work efficiency, but also promoted and enhanced professional ability of students majoring in financial management. Electronic examination improved learning and work efficiency of students and teachers, and saved time and resources. Thus, it was affirmed and welcomed by students and teachers. The comparison of satisfaction for electronic examination is shown in Table II.

\section{Comparison of examination scores}

Two hundred examination papers were drawn at random from control and experimental groups for statistical analysis of scores. The average score of students in control group is $(75.23 \pm 1.5)$, while that of students in experimental group is $(82.66 \pm 1.34)$. The score of students in experimental group is higher than that of the control group, and the difference has statistical significance $(\mathrm{p}<$ 0.01 ). Thus, the electronic examination system has important significance for promoting the academic score of students and facilitating the improvement of their learning ability and efficiency.

TABLE I.

COMPARISON OF EXAMINATION MODES OF BOTH GROUPS MAJORING IN FINANCIAL MANAGEMENT SPECIALTY

\begin{tabular}{|l|l|l|}
\hline \multicolumn{2}{|c|}{ Content } & \multicolumn{2}{c|}{ Experimental group } & Control group \\
\hline Number of examinees & 500 & 500 \\
\hline Examination room & $\begin{array}{l}4 \text { computer rooms and 6 classrooms or laborato- } \\
\text { ries }\end{array}$ & $15 \sim 20$ classrooms \\
\hline Examination time & $80 \sim 100 \mathrm{~min}$ & $100 \mathrm{~min}$ \\
\hline Time for examination paper composition & $1 \mathrm{~h}$ before examination & $2 \mathrm{w}$ before examination \\
\hline Task of examination paper composition & $\begin{array}{l}\text { Only set the difficulty proportion and question } \\
\text { type of examination paper }\end{array}$ & Cover teaching program \\
\hline Workload of examination paper production & None & $\begin{array}{l}\text { Include printing, sorting, binding and } \\
\text { packaging }\end{array}$ \\
\hline Number of examination monitoring teachers & $10 \sim 15$ & $30 \sim 40$ \\
\hline Paper inspection by teacher & Unnecessary & $2 \sim 3 \mathrm{~d}$ \\
\hline Test question revealing & Not easy & Easy \\
\hline Cheating & Not easy & Easy \\
\hline Connected with nationwide CPA examination guide & Connected & Not connected \\
\hline $\begin{array}{l}\text { Examination paper analysis and test question analy- } \\
\text { sis }\end{array}$ & Automatic generation & Manual statistics, large workload \\
\hline Human interference of test questions & None & Exist \\
\hline Human interference of test questions & None & Exist \\
\hline Students' learning enthusiasm & High & $\begin{array}{l}\text { Not high, make effort at the last moment } \\
\text { before examination }\end{array}$ \\
\hline Examination transparency & High & Low \\
\hline Automation, digitization & Complete & None \\
\hline
\end{tabular}

TABLE II.

COMPARISON OF STUDENTS' AND TEACHERS' SATISFACTION FOR ELECTRONIC EXAMINATION

\begin{tabular}{|l|c|c|c|c|}
\hline \multicolumn{1}{|c|}{ Type } & Experimental group & \multicolumn{2}{c|}{ Control group } & \multirow{2}{*}{ P } \\
\cline { 2 - 5 } & Number of people satisfied (\%) & Number of people satisfied (\%) & \\
\hline Teachers' satisfaction & $12(85.5 \%)$ & 6 & 42.3 & 0.018 \\
\hline Students' satisfaction & $280(93.3 \%)$ & 142 & 47.5 & $<0.001$ \\
\hline
\end{tabular}




\section{CONCLUSION}

Electronic examination and education platform is scientific and effective, compared with traditional teaching system. (1) Electronic examination and education platform also provides teachers with online paper inspection in the form of assembly line and accomplishes statistical analysis of data of all examinees, including distribution data, statistics of knowledge-point scoring rate, answer reappearance, and analysis of error answers. Such platform fully reflects the advantages of information-based examination in data era. Moreover, it contributes to teachers so they can know students' knowledge mastery situations better, and feed that information back to students to improve teaching quality. In addition, the platform effectively executes the principle of teaching-examination separation, saves the input of human and material resources, and guarantees examination fairness and effectiveness. (2) Electronic examination and education platform boosts answer accuracy, and reduces and simplifies operation difficulty of answering. Meanwhile, cheating during examination is effectively prevented through random generation of the order of different test questions and answers. Dual-identity authentication of student and ID cards is achieved through electronic equipment, which enhances validity of financial management examination. (3) Our future prospect is to further explore financial management teaching and examination. We plan to develop teaching and examination platform, which can be used on mobile terminals, such as tablet PCs and mobile phones, to break time and space restrictions; to achieve integration of financial management teaching and advanced information technology; and to promote development of financial management education actively.

\section{REFERENCES}

[1] Balaban M.A., Russell S., Mastaglio T.W., et al., "An approach to teaching port management aided by a constructive modelling and simulation environment," International Journal of Service and Computing Oriented Manufacturing, vol. 2, no. 2, pp. 155-178, June 2016. http://dx.doi.org/10.1504/IJSCOM.2016.076438
[2] Zhang T.W., Zhen G.H., Sui Z.L., "Construction of Curriculum System for Talents Cultivation of Vocational Education Teaching Staff in Vocational and Technical Teachers' College-The Case of Financial Management Specialty of Jilin Teachers' College of Engineering and Technology," Vocational and Technical Education, vol. 34, no. 2, pp. 5-9, January 2013.

[3] Qureshi M.R.J., "A proposal of electronic examination system to evaluate descriptive answers," Cell, vol. 27, no. 3, pp. 2143-2146, June 2015.

[4] Wu H.W., Yang X.Q., "Financial Management Course Teaching System Reform: Situation, Problems and Solutions," Journal of Bingtuan Education Institute, vol. 23, no. 2, pp. 56-62, April 2013.

[5] Yu P.F., Guo L., Feng Y., et al., "Cheating method and preventive measures of electronic examination," Experiment Science and Technology, vol. 12, no. 2, pp. 46-49, April 2014.

[6] Si B., "Study on examination system modeling under MVC mode," Computer Science, vol. 40, no. 6, pp. 403-406, June 2013.

[7] Wang J.H., Yang S., Zheng Y.X., "Study on examination system of higher teacher education technology specialty," Journal of Shenyang Normal University (Natural Science Edition), vol. 31, no. 3, pp. 413-416, September 2013.

[8] Bandele S O, Oluwatayo J A, Omodara M F. Opinions of Undergraduates on the Use of Electronic Examination in a Nigerian University. Mediterranean Journal of Social Sciences, vol. 6, no. 2, pp. 75, March 2015. http://dx.doi.org/10.5901/mjss. 2015.v6n2s1p75

[9] Osang F., "Electronic Examination in Nigeria, Academic StaffPerspective--Case Study: National Open University of Nigeria (NOUN)," International Journal of Information and Education Technology, vol. 2, no. 4, pp. 304-307, August 2012. http://dx.doi.org/10.7763/IJIET.2012.V2.137

[10] Long Y., Wu Q.H., Wang X.H., et al., "Design and application of paperless examination management system," Science and Technology Innovation Herald, vol. 10, no. 28, pp. 10-11, October 2013.

\section{AUTHORS}

Ying $\mathbf{Y u}$ is a Senior Accountant of Changsha Environmental Protection College, Changsha, China. Her research interests include Financial Management and electronic examination system. (2581646830@qq.com)

Submitted 07 August 2016. Published as resubmitted by the author 11 September 2016. 